\title{
Repositioning the use of the Bible towards a mission- oriented theological education
}

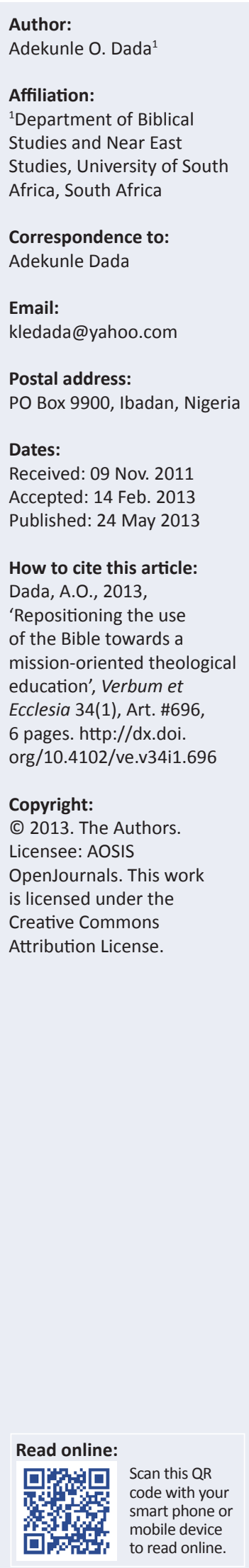

It is an undeniable fact that mission remains the cardinal essence of the Church. However, in Africa and in Nigeria, the Church seems to have lost focus regarding the main reason for its existence, namely mission. One of the factors responsible for this may be the form of theological education in vogue. In view of this anomaly, this paper reflects on how the study of the Bible, which serves as the primary basis for theological education in some institutions, can be repositioned to enhance a mission-oriented theological education. The importance of proper interpretation of the Bible in enhancing missions can be premised on the fact that a sound biblical hermeneutics is prerequisite to the formulation of an effective and functional theology of missions. If our theology of mission is faulty, the practice cannot be anything but flawed. In view of this, the paper explores ways in which the Bible can be meaningfully studied in order to promote a mission-oriented theological education.

\section{Introduction}

The need for theological education to be mission-oriented cannot be contested because mission remains the principal essence of the Church. The life and theology of the Church can only be meaningfully expressed and understood within the ambit of mission. This fact is better articulated by Bosch (1991):

Just as the Church ceases to be Church if it is not missionary, theology ceases to be theology if it loses its missionary character ... We are in need of a missiological agenda for theology rather than just theological agenda for mission; for theology, rightly understood, has no reason to exist other than to accompany the mission Dei. So mission should be 'the theme of all theology'. (p. 494)

In the light of the submission of Bosch above, it is evident that mission is the pivot of theological education. This is because theological education cannot be meaningful if not pursued in the context of mission. But a question arises: is theological education in Africa, especially in Nigeria, mission-oriented? This question arises from the fact that the quality of the faith of most of the Christians in Nigeria and their understanding and pursuance of mission works indicate that the question can possibly not be answered in the affirmative. This calls for sober reflection and a reassessment of the form and content of theological education in Nigeria.

This paper therefore reflects on the use of the Bible in theological education in Nigeria and how it can properly be repositioned to enhance a mission-oriented theological education in that country. The Bible holds tremendous possibilities for change and transformation if it is properly interpreted and its message effectively internalised. The relevance of a viable biblical hermeneutical methodology hinges on the fact that the Bible remains the principal reference point for many Christians in their perceptual field and character formation. This makes the Bible an important tool for education. The questions that form the fulcrum of this paper are: Has the Bible been properly utilised as an effective tool for transformation in theological education? Has the Bible been properly taught to meaningfully enhance mission study and practice? In what ways can the Bible be interpreted to enhance mission-oriented theological education?

\section{Present state of mission and theological education in Nigeria}

For a meaningful discussion of the issue at stake here, it is imperative to define what we mean by missions. Mission can broadly be described as a concept that seeks to re-establish the Christian theory and practice of mission in the Triune God; the mission of the Triune God is based on the sending nature of one divine person in the Trinity by another. The idea of missionary formation and practice has recently been linked with the church's divine sending into the entire world (Pachuau 2007:539). In essence, therefore, mission is the holistic communication and utilisation of the salvation message within the ambit of the mandate of the Triune God.

The beginning of mission in Nigeria can be traced to the activities of missionaries from the West and indigenous Africans, especially freed slaves. In spite of the successes of the Western 
missionaries in Nigeria their legacies - in terms of the quality and character of faith and mission vision and goal bequeathed to the people are without solid roots. The reason for this is that:

The missionaries set out in principle to convert 'pagan' to Christianity and to preach the Gospel, but in practice they also participated in denying the particularity of the Africans. No one can deny that some good things were done by the missionaries, but this must be weighed against the harm that was done against the people of Africa and their cultures. Western Christianity must face the fact that it was used against values it was intended to promote and defend. (Kanyandago 2003:43-58)

It must be underscored here that the missionaries contributed immensely to the social, educational and political lives of Africa. Sanneh (1989:153) opines that although criticism missionaries them is valid, we also have to recognise their immense contribution to the revitalisation of Africa. The missionaries were the first to actively pursue the task of bringing formal education to Africa. The first group of those educated in the schools established by the missionaries became freedom fighters that liberated Africa from the shackles of colonialism.

However, mission work is still carried out within the ambit of a Western template and Western models, despite the claim and clamour for indigenisation. The effect of this is not difficult to see. Nigeria is reputed to be one of the countries where Christianity is growing rapidly, but the quality of this growth may be questioned. The relevance of this question becomes clear when one considers the fact that some Nigerian Christians embrace traditional religion and Christianity simultaneously. They attend church service during the day and shrine service at night. Although Christianity has spread widely in Nigeria, it is without deep roots in the lives of the people (Dzurgba 1995:121). Can we say that mission work in Nigeria has been highly successful when this situation is considered?

Furthermore, a popular form of mission work in Nigeria today is what Mugambi (2008:153) terms 'tourist evangelism'. This is a form of mass evangelism by notable Western evangelists whose goal, according to the organisers, is to win souls for Christ. The growth of materialism and secularisation in Europe and North America may have something to do with the rise of these evangelistic outreaches in Nigeria and Africa as a whole. During the Cold War, there was a deliberate effort from North Atlantic missionaries to spiritualise African Christianity and protect Africans from the materialism and secularism associated with communism. The Christian enterprise came to be openly associated with capitalism. Tourist-evangelists became, at the same time, harvesters of African souls and promoters of Euro-American values and virtues.

In Nigeria this form of evangelisation was popularised by the late Benson Idahosa who was extensively influenced by popular American evangelists like T.L. Osborn and the late Oral Roberts. The major features of this kind of mass evangelism were miracles and prosperity. There were always massive advertisements in the print and electronic media highlighting the powers of the evangelists as having the key to people's existential needs. Crowds were often drawn to their campaigns because of the razzmatazz that characterised them. But the souls that were claimed to have been won for Christ at these events often returned to their former lifestyles because the foundation of their faith was not solid. In some quarters, these forms of mission work have been condemned as having no solid biblical basis, and as nothing more than a means of glamorising the evangelists and making money.

In the same vein, specialised or institutionalised theological education in Nigeria today tend to concentrate more on training personnel solely for church ministry. Mission does not seem to be a major focus in some theological institutions. This is evident in the curricula of these institutions. One of the major reasons for this may be that some of these institutions were mainly conceived and founded as a training ground for ministers that were to take charge of the churches founded by the missionaries. Another reason why theological education in Nigeria does not function effectively in the area of mission may be that the training institutions still operate according to Western templates and models. Some of these institutions were founded by Western missionaries whose worldviews were at variance with those of the students. The weakness of the missionary paradigm in theological education and its operation are best described by Akrong (2007):

The dominant paradigm in modern missionary theology produced a theology of salvation that drew African 'pagan' into the orbit of universal salvation through incorporation into Western Christendom; this implied the exclusion and rejection of African culture. Missionary theology was controlled by this paradigm. In real terms, this meant that the African who was able to abandon his or her 'pagan' culture could be assimilated into Western culture, and into the orbit of universal salvation. Those who still persisted in the African 'pagan' culture were held to be damned and excluded from God's universal history of salvation. (p. 25)

The major weakness of the missionary paradigm in theological education, even where mission is made the main focus, is the alienation of the beneficiaries from their roots and also the distortion of the basic concepts and teachings it offers. This could have happened because the Western discourse had its own language, which, when imposed upon people raised with different configurations of learning, resulted in alienation, distortion and dependence (Ngugi 1986:124). One area where alienation, distortion and dependence are obvious is the way in which the Bible is used in theological education. A casual perusal of the curricula of some theological institutions revealed that the courses on the Bible were conceived mainly to inform students about the ancient backgrounds from which the text emanated. From the way some of these courses are described, one can deduce that they aid the cognitive and affective expertise of the students, but leave their psycho-motor domains unaffected. It is only when the meaning of the text is drawn out and properly internalised that a change in the perception of the student can be effected. 
However, it may not be possible to affirm confidently that the hermeneutical methodology employed in the study of the Bible has promoted a proper understanding of the meaning of the text, one which will ultimately enhance mission. This is because, according to Tienou (1984):

In our teaching, both in Church and our theological institutions, we tend to satisfy ourselves with the knowledge of proper information, the proper content of the Bible. But we often miss the all-important factor: the meaning. We should not therefore be surprised that we have built a hollow Christianity: a Christianity of meaningless words! Sense and not sound must be our theological aim. The understanding of the intended sense of the scripture will go a long way towards the maturity of our people. (p. 301)

From this observation it is evident that the proper interpretation of the biblical text is a prerequisite for the formulation of an effective and functional theology for missions. If our theology of mission is faulty, then the practice cannot be anything but flawed. In the light of this, therefore, it is clear that the study of the Bible should occupy the central position in theological education in the Nigerian context. The Bible should be the hub around which other courses revolve. The goal of the study of these other courses is to ensure that the biblical text is meaningfully expounded and applied. In some instances the reverse seems to be the case. In view of this, we shall explore ways in which the Bible can be meaningfully studied in order to enhance a missionoriented theological education.

\section{Repositioning the use of the Bible towards mission-oriented theological education}

In $1900,77 \%$ of the world's Christian population lived in Europe and Northern America. In 2000, only 37\% of the two billion Christians in the world lived in the northern continents; whilst 63\% were from Asia, Oceania, Africa, and Latin America. The projection for 2025 is $29 \%$ and $71 \%$, respectively (Barrett \& Johnson 2001:23). The implication of these statistics for Africa, especially south of the Sahara, is that there is going to be an upward swing in the population of Christians. This poses challenges for an effective theological education in the Nigerian context. This is because mission without agreement on core issues of theology is more than useless. It is an abomination to God and it is harmful to both the evangeliser and the evangelised. Corwin (2003:147) has highlighted the purpose of theology in missions. The first dimension of this purpose is what he calls the vertical dimension, which enables people to understand rightly (though certainly not perfectly) the Triune God, and to relate properly to him. This is as essential for the recipients of the gospel as it is for those who carry it to them. The second is the horizontal dimension. Good theology is the indispensible prerequisite for believers to understand rightly and to relate properly to both their environment and others. Although the relationship with the environment is beyond our scope here, the relationship with other people is vital, both in connection with other believers (body life) and with those who are outside the faith (evangelism and mission). The third dimension is that theology is central to the 'all things' that Jesus commanded us to teach his disciples. This is done primarily by 'teaching those are able to teach others also' (2 Tm 2:2); hence the need for theological education and leadership training as vital aspects of missions (Corwin 2003).

For theology of mission to be authentic it must be biblically rooted. Also, a proper interpretation of the Bible is necessary for biblical theology. For theological education to be missionoriented and effective, a viable methodology for the use of the Bible as medium of instruction and training must be adopted. This is important because the hermeneutical methodology currently in use is mainly derived from the West. The consequences of this for theological education and the life of the Church in the West are better revealed by Asamoah-Gyedu (2007):

If the Bible has lost its place as source of guidance for public life and morality in the West, it did so by first losing its status as more than a sacred book through a process of biblical relativism and gradual demystification. Critical hermeneutical methods of biblical interpretation may have their place in theology, but unreflective adoption of such academic methods has contributed significantly to this demystification of the Bible, and thus to the decline of Christian presence in the modern West. (p. 19)

If the Bible is to be effectively deployed as an effective instrument for the kind of spiritual formation, individual change and transformation which will ultimately enhance a mission-oriented theological education, it is imperative to devise a suitable and viable hermeneutical methodology that will allow these goals to be realised. The need or necessity for a viable biblical hermeneutics in Nigerian theological education hinges on three factors. The first is that the Bible cannot be meaningfully interpreted outside the socio-cultural context of the reader. Therefore every hermeneutical method should be situated within a specific context. Secondly, it is necessary to break the stranglehold the West has on the biblical hermeneutical methods currently employed in Nigerian educational institutions. Finally the need to continue to make the Christian faith relevant in the face of changing social, economic and political realities is a compelling one.

In order to make theological education mission-oriented via the effective utilisation of the Bible the following hermeneutical guidelines are suggested.

Christological in character: Biblical hermeneutical methodology in theological education must be uncompromisingly Christological in character. Christ is the centre of Christianity and his break into the realms of humanity still remains the defining moment in history. Therefore our utilisation of the biblical text in theological education should aim at a functional Christology. This is a Christology derived from the people's experience of Christ in their social-cultural setting. If this fact is neglected, Christ will not be fully understood and effectively communicated to others within and outside the Church. Cone (1999) avers that:

The interplay of social context with scripture and tradition is the starting point for an investigation of Jesus Christ meaning for today. The focus on social context means that we cannot separate 
our questions about Jesus from the concreteness of everyday life. We ask, 'who is Jesus Christ for us today?' because the story of his life and death is the answer to the human story of oppression and suffering. If our existence were not at stake, we did not experience the pain and the contradictions of life, and then the Christological question would be no more than an intellectual exercise of professional theologians. (p. 40)

If our use of the Bible in the process of a Christological construct is not to remain a mere academic exercise, the adequacy of Christ for the totality of human experiences must be high on the agenda. This is because there is real evidence that Christians who newly profess their faith often limit Christ to prescribed areas of their lives. When it comes to the major crises of life, such as sickness, suffering and death, Christ is pushed aside and recourse is made to traditional and well-proven methods to counter the effects of evil and gain assurance in a world of uncertainty and danger. It can be argued that people who do this had not truly been converted, but the fact cannot be gainsaid that the picture of Christ that had been presented them in the first place did not properly fit into their scheme of things. Hence, most Africans tend to uphold two faiths - they maintain the Christian faith when life is gay and happy, but hold to the indigenous faith when the fundamentals of life are at stake (Imasogie 1985:58).

One's apprehension of Christ as God's answer to human needs is crucially influenced by one's culture. As Imasogie (1985:58) observed, this creates the need to overhaul the current theological curricula, which had been devised in a different culture to meet the specific needs of that time. This is necessary if theological education is to equip the minister for meeting the total needs of the people in their cultural setting. Overhauling does not necessarily mean that existing curricula will be discarded. Some elements are basic and must be retained, but this will be done because they are found, after objective evaluation, to be universally relevant. The call for a biblical hermeneutical methodology that is Christological in character can be justified in the light of this background.

Contextual in orientation: A biblical methodology that will enhance a mission-oriented theological education must be contextual in orientation. Contextual biblical hermeneutics in Africa is biblical interpretation that takes African social, cultural, political and economic contexts in consideration. Specifically it means that analysis of the text is done from the perspective of an African worldview and culture (Adamo 2001:6).

Different contextual biblical hermeneutical approaches have emerged in Africa. One of these is the African comparative approach. This is a hermeneutical principle that relates the biblical texts to the African context by comparing the convergence and divergence of the African and biblical worlds. The 'reading with the ordinary reader' approach was popularised by West, a South African Bible scholar. This is an approach that seeks to mediate between critical and pre-critical readings of the Bible. In other words, it tries to take seriously the interpretation of the ordinary reader of the Bible, under the guidance of a trained reader (West 2003).
The liberation approach is an interpretation schema that engages the Bible in the course of socio-political liberation. The work of South African scholars such as Nolan, Mosala, Chikana and Mofokeng represent this school of biblical interpretation. Another popular contextual approach to the Bible in Africa is the 'Bible as power' approach. The major proponent of this approach is Adamo (2004:24-26) of Nigeria. This is an 'existential' and 'reflective' approach to the interpretation of the Bible. The Bible is used as a means of protection, healing and success. This method is mostly prevalent amongst the African indigenous churches. Another contextual biblical hermeneutics that makes African culture a subject of interpretation is the bosadi woman approach. According to the chief exponent of this approach, Madipoane Masenya (2005:741-751) of South Africa, the bosadi approach is not simply a comparative analysis of the biblical text and the African culture, but an approach that critiques both cultures and texts not only in terms of gender concerns, but also in terms of of class, and 'woman-as-strange' and 'African-asstrange' in their own territory. Although the bosadi approach is an attempt to resuscitate African culture from the ashes, it does not idolise it.

In the same vein Ukpong (2005:35) has proposed what he calls 'biblical inculturation'. This is a dynamic, ongoing process by which people consciously and critically appropriate the Bible and its message from within the perspectives and with the resources of their culture. Manus' intercultural hermeneutics is similar in ethos to that of Ukpong. Intercultural hermeneutics is a descriptive paradigm that seeks to address grass-roots Christians in their actual contexts and social location in Africa (Manus 2003).

There are other emerging methods of biblical interpretation in Africa. However, one common denominator of these hermeneutical approaches is that they arose from and aim to address a particular or specific context. Their contextual character, therefore, makes it possible for them to be classified as contextual biblical hermeneutics.

The inescapability of contextual biblical hermeneutics in Africa can be explained by the fact that reading the Bible always occurs within a social context, whether it is acknowledged or not. Readers will always be located in their community of faith, which is a microcosm of their larger society. Some of these scholars claim that it is difficult, if not impossible, to fully discard their innate Africanness in spite of the influence of Western cultures. As Schreiter (2007) observes, new questions are being asked, questions for which there are no ready traditional answers. Indeed, so many new questions are emerging that the credibility of existing forms of biblical hermeneutics is weakened.

Riches (1996:187) has, however, raised an alarm in that the fact that a contextual reading of the text poses the problem of normativity. The particularity of a local reading may estrange people from one another. The imposition of a universal God on other communities may be oppressive and impoverish their culture. The particularity of the local reading may, in the 
end, become a denial of a common humanity. He says that we are all caught in the same web and need one another's voices if we are not to deny ourselves by denying our very interrelatedness.

Whilst Riches' concern may be entertained to some extent, it should be underscored that it is, indeed, difficult if not totally impossible to arrive at a uniform or universal reading and interpretation of the text. This is because our contexts always influence our reading of the Bible to some extent. Our race, culture, gender and class influence our reading of the Bible. The Bible also emanated from different socio-cultural and literary contexts.

Moreover, one of the pitfalls of contextual biblical hermeneutics is that mission is not given extensive priority. Social, political and cultural issues tend to be the motivating force behind them. This is perhaps an indication that not all contextual readings are in line with the essential tenets of the gospel (Verstraelen 1993). To make our theological education mission-oriented we need to find a viable contextual hermeneutical option which will facilitate missions by seeking ways in which Christ can be better understood and communicated in the African context.

Holistic methodologies: To ensure that the message of the Bible have a lasting and positive effect as a tool of education and to enhance mission-oriented theological education, a wide range of hermeneutical methodologies must be utilised. According to Wright (2006:184), a missional hermeneutic must include, at least, a recognition of the multiplicity of perspectives and contexts from which and within which people read the biblical texts. Even when we affirm that the historical and salvation-historical context of biblical texts and their authors are of primary and objective importance in discerning their meanings and significance, we need to remember that the plurality of perspectives from which readers read is also a vital factor in the hermeneutical richness of the global church.

It is customary for some African biblical scholars to condemn every Western-oriented hermeneutical methodology as oppressive and evil. Some Western and Euro-centric biblical scholars in Africa, on the other hand, see contextual biblical hermeneutics as nothing but a handmaiden of African renaissance which will ultimately lead to Christo-paganism, a mixture of Christianity and elements of traditional African religions. Jonker's (2005:643) warning that a multidimensional approach to biblical interpretation can help us to escape the looming dangers of exclusivism in our exegetical endeavours is apt in the Nigerian context. Biblical scholars in Africa tend to step into one of two abysses; either to claim that their own methods are the only ones that can deliver true, meaningful results, or to claim that their own life interests are the only legitimate vantage point into the biblical text. A multidimensional or holistic approach would steer us away from exclusivism.
Our biblical scholarship should remain open to any method, past or present, that best serves its purpose. Western and other hermeneutical methodologies should not be swallowed hook, line and sinker. We should critique these hermeneutical traditions and use an exegetical approach and strategy that suits the African context. It is gratifying to note that some biblical scholars employing the Western methodologies are also gradually becoming more open to influences from the context-oriented approaches. It is when we properly and effectively integrate the different available methodologies that the Bible can be effectively used in theological education and mission.

Holistic worldview: If a biblical hermeneutics is to be relevant and effective in theological education and missions, it must address the holistic worldview of the Africans. The compartmentalisation of reality into the realms of the sacred and profane is strange to traditional African society. To them reality is a unified whole. For example, salvation in the African context is about deliverance not only of the soul, but also of the body. What is the essence of a salvation that guarantees the freedom of the soul but not that of of the body?

Moreover, the worldview of most Africans is still to a great extent primal, even in modern times. For example, the belief in the existence of witchcraft and other malevolent forces is still rife. Even educated and enlightened Christians hold tenaciously to beliefs that are regarded as superstitions in some quarters. For any interpretation to be grounded in the people's consciousness - thereby enhancing mission work it must take into cognisance the people's worldview. After all, the entire Bible takes into consideration the worldview of the people of the period in which and for whom it was written.

Connection with the community: If theological education is to be mission-oriented, the biblical hermeneutical methodology employed must also connect with the community. If we want to reconstruct missions from the perspective of God's creation, we have to read the Bible with new eyes that will enable us discern God' activities in our neighbourhood and in the faith of the people. Theological education, therefore, has to enable and to empower theological students to identify with the history and cultures of their people (NanJou 2008:188). A biblical hermeneutics rooted in praxis is essential if we are to sustain an evangelical witness in Nigeria. As Bevans (1992:25) observes, the praxis model of contextual theology is insightful in that theology is practiced not simply by providing expressions of Christian faith, but also by a commitment to Christian action. Moreover, theology is then understood as the product of the continual dialogue of these two aspects of Christian life.

The weakness of most of the Western oriented and contextual biblical hermeneutical methodologies employed in theological education in Nigeria is that they are detached from the community of faith. This is because most of the contextual approaches to biblical interpretation have not had a direct bearing on the church. Most of the scholars involved in devising new methods of biblical interpretation 
are academics in the seminaries and universities. The fruits of their enterprise rarely have a direct impact on mission and on the ordinary people in the church. An interpretative enterprise that would enhance a mission-oriented theological education must be one that takes into cognisance what ordinary people are saying at grass-roots level about their understanding of the Bible. According to Onaiyekan (2001), the Catholic Archbishop of Abuja, Nigeria:

We need to find a way of listening to - and documenting - what our people are hearing from the Scriptures. If the Holy Spirit is the main interpreter of the Bible, we must be convinced that the Bible speaks not only through professional exegetes with academic degrees and qualifications but also, and I would say above all, through all those who live in union with God. This is one of the many lessons I have learnt since I left active professional biblical academics into the field of full-time pastoral engagement. (pp. 5-6)

Position of the Holy Spirit: If we want our teaching of the Bible to promote a mission-oriented theological education, the Holy Spirit must be accorded prime position in our hermeneutical activities. The Holy Spirit can illuminate and direct the harnessing of the fruits of our interpretation properly, so that we arrive at the truth and its proper application. Whilst it is important not to discourage rigorous and analytical study of the texts, it is equally important to remember that the Holy Spirit has an important role to play in the interpretative process. Some biblical hermeneutical methodology seems to deny and de-emphasise supernatural elements in the process of meaning production at the expense of rational or empirical considerations. However, if we confess God as the ultimate author of the biblical text, it is not out of place to depend on him for the ultimate meaning of the text.

\section{Conclusion}

The fact that the Bible plays an important role in theological education is incontestable; hence the need for a suitable methodology that would aid its interpretation, application and teaching. However, if the Bible is to enhance a missionoriented theological education it must be Christo-centric, contextual, and people and community oriented; and the Holy Spirit must be accorded unrestricted space in the interpretative process. If we want to achieve this goal in our theological education, constant assessment of the way we use the Bible in our pedagogical activities becomes necessary. This can best be done by a constant review of the theological education curricula in order to promote efficiency and optimal performance by students and even faculty.

In the process of pursuing this task, it should be remembered that theological education should not be an end in itself. It should lead to service, practical and selfless service to humanity - something which is best done in the context of missions. A theological programme, regardless of how garnished with highbrow scholarship it may be, is useless and an exercise in futility if it is forever encased in abstraction without any correspondence with reality. Theology can become relevant only when it effectively equips for mission and ministry and helps to deal with the real challenges that are faced by real people in a real world (Ehioghae 2005:59).

\section{Acknowledgements Competing interests}

The author declares that he has no financial or personal relationship(s) which may have inappropriately influenced him in writing this article.

\section{References}

Adamo, D.T., 2001, Reading and interpreting the Bible in African indigenous churches, WIPF and Stock Publishers, Eugene, Oregon.

Adamo, D.T., 2004, Decolonizing African biblical studies, Delta State University, Abraka, Nigeria.

Akrong, A., 2007, 'The challenges of theological education in Ghana', Journal of African Christian Thought 10(2), December, 24-30.

Asamoah-Gyedu, J.K., 2007, 'Beyond text and interpretation: The Bible as a book of sacred power in African Christianity', Journal of African Christian Thought 10(2), December, 18-23.

Barrett, D.B. \& Johnson, T.M., 2001, 'Annual statistical table on global mission', International Bulletin of Missionary Research 25(1), January, 15-28.

Bevans, S.B., 1992, Models of contextual theology, Orbis Books, Maryknoll, New York. PMid:1447583

Bosch, D., 1991, Transforming mission: Paradigm shift in the theology of missions, Orbis Books, Maryknoll, New York.

Cone, J.H., 1999, 'Who is Christ for us today', in E.M. Uka (ed.), Issues in theology, mission, church and society, pp. 36-58, Clear-Lines Publications, Calabar, Nigeria.

Corwin, G., 2003, 'The mission of theology in missions', Evangelical Missions Quarterly, April, 135-148

Dzurgba, A., 1995, 'Religion and anthropological studies in Africa: The scope of social anthropology of religion', Journal of Asian and African Studies, September, 118-132.

Ehioghae, E.M., 2005, 'Towards a primacy of spirituality in theological education', in E. Martey, P. Kemdirim \& D. Ayegboyin (eds.), Spirituality and theological education in West Africa, pp. 47-59, West Africa Association of Theological Institutions, Accra.

Imasogie, O., 1985, 'Contextualization and theological education', Evangelical Review of Theology, January, 50-62.

Jonker, L., 2005, “'Contextuality” in (South) African exegesis, Reflection on the communality of our exegetical methodologies', Old Testament Essays 18(3), 637-650.

Kanyandago, P., 2003, 'The experience of negation of particularity and Africa's struggle for survival', Chakana: Intercultural Forum of Theology and Philosophy, 43-58.

Sanneh, L., 1989, Translating the message: Missionary impact on culture, American Society of Missiology, Atlanta.

Manus, C.U., 2003, Intercultural hermeneutics in Africa: Methods and approaches in contemporary biblical studies in African scholarship, Acton Publishers, Nairobi.

Masenya, M., 2005, 'An African methodology for South African biblical sciences, Revisiting the bosadi (womanhood) approach', Old Testament Essays: Journal of Old Testament of Society of South Africa 18(3), 741-751.

Mugambi, J.N.K., 2008, 'Some reflection on tourist evangelism in tropical Africa', Theologies and Cultures, December, 151-180.

Nan-Jou, C., 2008, 'Towards a mission-oriented theological education', Theologies and Cultures, December, 181-191.

Ngugi, W.T., 1986, Decolonizing the mind: The politics of language in African literature, James Currey, London.

Onaiyekan, J., 2001, 'Current biblical hermeneutics in Africa', African Journal of Biblical Studies April, 1-6.

Onwurah, E., 1999, 'The quest, means and relevance of African Christian theology', in E.M. Uka (ed.), Issues in theology, mission, church and society, pp. 20-34, ClearLines Publication, Calabar.

Pachuau, L., 2007, “'Missio Dei”', in J. Corrie (ed.), Dictionary of mission theology, pp. 232-233, Inter-Varsity Press, Nottingham.

Riches, J., 1996, 'Interpreting the Bible in African contexts: Glasgow consultation', in G. West \& M.W. Dube (eds.), 'Reading with': An exploration of the interface between critical and ordinary readings of the Bible, pp. 165-198, Scholar Press, Atlanta.

Schreiter, R.J., 2007, Constructing local theologies, Orbis Books, Maryknoll, New York.

Tienou, T., 1984, 'The church and its theology', in M. Maloti, P. Johnson \& J. Martins (eds.), The church in Africa: Today and tomorrow, pp. 285-301, Evangelical Publishing House, Nairobi.

Ukpong, J.S., 2005, 'Inculturation as decolonization of Biblical studies in Africa', in S.O. Abogunrin (ed.), Decolonization of Biblical interpretation in Africa, Nigerian Association for Biblical Studies, Ibadan.

Verstraelen, F.J., 1993, 'The Christian Bible and African cultural realities', in J.L. Cox \& F.J. Verstraelen (eds.), Rewriting the Bible: The real issues, Department of Religious Studies, Classics \& Philosophy, University of Zimbabwe, Harare.

West, G., 2003, Contextual Bible study, Cluster, Pietermaritzburg.

Wright, C.J.H., 2006, The mission of God: Unlocking the Bible's grand narrative, InterVarsity Press, Leicester, England. 